\title{
PENINGKATAN KEMAMPUAN KOMUNIKASI MATEMATIS DAN MOTIVASI BELAJAR SISWA DENGAN MENERAPKAN MODEL PEMBELAJARAN EXPERIENTIAL LEARNING
}

Oleh:

Lili Nur Indah Sari ${ }^{1}$

Email : lilidly89@gmail.com

\begin{abstract}
The ability of students to solve math problems is still not satisfactory despite the efforts of many teachers to improve their abilities. This is because the teacher in the learning process conditions students in the memorization stage of what they have learned and not experiences their own concepts obtained during learning so that students lack motivation to follow existing learning. One learning strategy that is expected to improve mathematical communication skills and student learning motivation is by applying Experiential Learning learning models. The experiential learning model is intended so that during learning students construct their own experiences so that they are able to communicate express ideas, read, write and represent mathematical concepts and discuss and accept the opinions of their friends in groups. The purpose of this research is to find out (1) whether the Experential Learning learning model can improve students' mathematical communication skills. (2) Whether the Experiential Learning model can improve student learning motivation. This research method is quasi-experimental design. Data collection techniques in this study through students' mathematical communication skills test and learning motivation questionnaire. Data analysis is done by quantitative techniques. The results showed that Experiential Learning learning models could significantly improve mathematical communication skills and student learning motivation. The average value of the experimental class and control class after the teaching and learning process has increased from the average values of the two pre-test classes, namely 78.79 and 72.33. Based on the results of calculations and testing student learning motivation using the Tukey test at $\alpha=0.05$ for testing student learning motivation, obtained $Q$ count $=8.05$ greater than $Q$ tabel $=4.08$.
\end{abstract}




\section{Abstrak}

Kemampuan siswa untuk memecahkan masalah matematika masih belum memuaskan meskipun ada upaya dari banyak guru untuk meningkatkan kemampuan mereka. Ini karena guru dalam proses pembelajaran mengkondisikan siswa dalam tahap menghafal apa yang telah mereka pelajari dan tidak mengalami konsep mereka sendiri yang diperoleh selama pembelajaran sehingga siswa kurang motivasi untuk mengikuti pembelajaran yang ada. Salah satu strategi pembelajaran yang diharapkan dapat meningkatkan keterampilan komunikasi matematis dan motivasi belajar siswa adalah dengan menerapkan model pembelajaran Experiential Learning. Model experiential learning dimaksudkan agar selama pembelajaran siswa membangun pengalaman mereka sendiri sehingga mereka dapat mengkomunikasikan ide-ide yang diungkapkan, membaca, menulis dan mewakili konsep matematika dan mendiskusikan dan menerima pendapat teman-teman mereka dalam kelompok. Tujuan dari penelitian ini adalah untuk mengetahui (1) apakah model pembelajaran Experential Learning dapat meningkatkan kemampuan komunikasi matematis siswa. (2) Apakah model Experiential Learning dapat meningkatkan motivasi belajar siswa. Metode penelitian ini adalah desain kuasi eksperimen. Teknik pengumpulan data dalam penelitian ini melalui tes kemampuan komunikasi matematis siswa dan angket motivasi belajar. Analisis data dilakukan dengan teknik kuantitatif. Hasil penelitian menunjukkan bahwa model pembelajaran Experiential Learning dapat secara signifikan meningkatkan keterampilan komunikasi matematika dan motivasi belajar siswa. Nilai rata-rata kelas eksperimen dan kelas kontrol setelah proses belajar mengajar telah meningkat dari nilai rata-rata dari dua kelas pre-test, yaitu 78,79 dan 72,33. Berdasarkan hasil perhitungan dan pengujian motivasi belajar siswa menggunakan uji Tukey pada $\alpha=0,05$ untuk menguji motivasi belajar siswa, diperoleh $Q$ hitung = 8,05 lebih besar dari Qtabel = 4,08.

Kata Kunci: Kemampuan Komunikasi Matematis, Motivasi Belajar dan Model Pembelajaran Experiential Learning. 


\section{PENDAHULUAN}

Matematika merupakan salah satu bidang studi yang sangat penting, baik bagi siswa maupun bagi pengembangan bidang keilmuan yang lain karena matematika merupakan kunci utama dari pengetahuan-pengetahuan lain yang dipelajari di sekolah sebagai lembaga pendidikan. National Research Counci dari Amerika Serikat telah menyatakan: "Mathematics is the key to opportunity." Matematika adalah kunci ke arah peluang -peluang keberhasilan. ${ }^{1}$

Kedudukan matematika dalam dunia pendidikan sangat besar manfaatnya antara lain sebagai alat dalam pendidikan perkembangan dan kecerdasan akal. Selain itu, matematika juga bermanfaat untuk masyarakat dalam kehidupan sehari-hari. Hal ini sesuai dengan yang dikemukakan oleh Soejadi yang mengatakan bahwa "tujuan dari pendidikan matematika pada jenjang pendidikan dasar dan menengah adalah menekankan pada penataan nalar dan pembentukan kepribadian (sikap) siswa agar dapat menerapkan atau menggunakan matematika dalam kehidupannya".

Namun, untuk mempelajari matematika itu tidak mudah agar berguna dalam kehidupan sehari-hari. Hal ini terlihat jelas dari rendahnya nilai matematika siswa daripada mata pelajaran lain. Ini disebabkan oleh beberapa faktor. Salah satu faktor kesulitan yang dihadapi yakni guru kurang komunikatif dalam menyampaikan ide matematikanya di dalam kelas dan hanya mempergunakan bahasa-bahasa angka sehingga matematika identik dengan pelajaran yang abstrak dan jauh dari pikiran mereka. Hal ini sesuai dengan yang dikemukakan oleh salah satu siswa MTsN 2 Padangsidimpuan (melalui wawancara awal sebelum peneliti melakukan penelitian) yang mengatakan bahwa :

Matematika adalah pelajaran yang di dalamnya hanya terdapat angka-angka dan simbol-simbol abstrak yang tidak ada manfaatnya dalam kehidupan sehari-hari. Selain itu, selama proses pembelajaran guru hanya menerjemahkan bahasa buku dan jarang menggunakan alat peraga atau contoh dalam kehidupan sehari-hari. Akibatnya, siswa mengalami kesulitan dalam menerjemahkan bahasa dan simbol matematika secara lisan maupun tulisan sehingga konsep yang diberikan tidak diperoleh siswa.

Hal ini terbukti dari nilai rata-rata hasil belajar siswa pada materi lingkaran masih rendah yaitu di bawah nilai KKM sebagaimana yang tertera dalam tabel berikut:

1 Nelissen, J.M.C. (2005). Thinking Skill in realistics mathematics. Jmc_nelissen: Journal PME. Vol 2 p 108-119 2005. 
Tabel 1 Nilai rata-rata hasil belajar siswa kelas VIII MTsN 2 Padangsidimpuan

\begin{tabular}{|c|c|c|}
\hline Kelas & $\begin{array}{c}\text { Nilai Rata- } \\
\text { Rata }\end{array}$ & \multirow{2}{*}{ KKM } \\
\hline VIII-A & 60 & \multirow{2}{*}{61} \\
\hline VIII-B & 58 \\
\hline VIII-C & 64 & \\
\hline VIII-D & 57 \\
\hline $\begin{array}{l}\text { Rata- } \\
\text { rata }\end{array}$ & 60 & \\
\hline
\end{tabular}

Untuk mengatasi permasalahan tersebut, diperlukan seorang guru yang kreatif, inovatif dan menyenangkan serta memiliki pengetahuan tentang modelmodel pembelajaran agar pembelajaran yang dilakukan dapat bermakna bagi siswa sehingga mereka memahami penggunaan matematika dalam kehidupan sehari-hari. Salah satu upaya mengatasi kesulitan siswa dalam kemampuan komunikasi mengungkapkan ide, membaca, menulis dan merepresentasi konsep matematika serta berdiskusi dan menerima pendapat temannya dalam kelompok pada materi lingkaran mengenai unsur-unsurnya yakni menerapkan model pembelajaran experiential learning.

Tujuan penelitian ini untuk meningkatkan komunikasi matematis siswa dan motivasi belajar mereka selama proses pembelajaran berlangsung dengan menerapkan model pembelajaran experiential learning dengan materi unsurunsur lingkaran.

Bagaimana Peningkatan Kemampuan Komunikasi Matematis Dan Motivasi Belajar Siswa dengan Menerapkan Model Pembelajaran Experiential Learning?

Secara umum, komunikasi dapat diartikan sebagai proses menyampaikan pesan dari seseorang kepada orang lain baik secara langsung (lisan) ataupun tidak langsung (melalui media). Abduhalk "komunikasi sebagai proses penyampaian pesan dari pengirim pesan kepada penerima pesan melalui saluran tertentu dan untuk tujuan tertentu". Ada tiga bentuk komunikasi, yaitu komunikasi linear atau satu arah, komunikasi relasional atau interaksi, dan komunikasi konvergen atau multiarah. Kemampuan komunikasi matematis adalah kemampuan siswa dalam menyampaikan ide matematika baik secara lisan maupun tulisan. Kemampuan 
komunikasi matematis peserta didik dapat dikembangkan melalui proses pembelajaran di sekolah, salah satunya adalah proses pembelajaran matematika. ${ }^{2}$

Matematika adalah bahasa yang melambangkan serangkaian makna dari pernyataan yang ingin disampaikan. Menurut Fathoni matematika dipandang sebagai bahasa karena "dalam matematika terdapat sekumpulan lambang/simbol dan kata (baik kata dalam bentuk lambang)". Misalnya " >" yang melambangkan kata "lebih besar", maupun kata yang diadobsi dari bahasa biasa, misalnya kata "fungsi" yang dalam matematika menyatakan suatu hubungan dengan aturan tertentu antara unsur-unsur dalam dua buah himpunan. Simbol-simbol matematika bersifat "artificial' yang baru memiliki arti setelah sebuah makna diberikan kepadanya. Tanpa itu, maka matematika hanya merupakan kumpulan simbol dan rumus yang kering akan makna. Berkaitan dengan hal ini, tidak jarang dijumpai dalam kehidupan, banyak orang yang berkata bahwa $\mathrm{X}, \mathrm{Y}, \mathrm{Z}$ itu sama sekali tidak memiliki arti.

Greenes dan Schulman mengatakan bahwa komunikasi matematika merupakan: ${ }^{3}$

1. kekuatan sentral bagi siswa dalam merumuskan konsep dan strategi matematik

2. Modal keberhasilan bagi siswa terhadap pendekatan dan penyelesaian dalam eksplorasi dan investigasi matematik

3. Wadah bagi siswa dalam berkomunikasi dengan temannya untuk memperoleh informasi, membagi pikiran dan penemuan, curah pendapat, menilai dan mempertajam ide.

Sedangkan komunikasi matematis meliputi kemampuan siswa:

1. Menghubungkan benda nyata, gambar, dan diagram ke dalam idea matematika;

2. Menjelaskan idea, situasi dan relasi matematik secara lisan atau tulisan dengan benda nyata, gambar, grafik dan aljabar;

3. Menyatakan peristiwa sehari-hari dalam bahasa atau simbol matematika;

4. Mendengarkan, berdiskusi, dan menulis tentang matematika;

5. Membaca dengan pemahaman atau presentasi matematika tertulis;

\footnotetext{
2 Hodiyanto, Kemampuan Komunikasi Matematis dalam Pembelajaran Matematika, Jurnal AdMathEdu / Vol.7 No.1 Juni 2017, hlm. 1

3 Sri Wardhani. Analisis SI dan SKL mata pelajaran matematika SMP/MTs untuk optimalisasi tujuan mata pelajaran matematika. Yogyakarta: Pusat Pengembangan dan

Pemberdayaan Pendidik nan Tenaga Kependidikan Matematika. 2008, hlm. 19.
} 
6. Membuat konjektur, menyusun argument, merumuskan definisi dan generalisasi;

7. Menjelaskan dan membuat pertanyaan tentang matematika yang telah dipelajari.

Dari beberapa definisi di atas dapat disimpulkan bahwa kemampuan

komunikasi dalam matematika adalah kemampuan siswa membaca wacana matematika dengan pemahaman, mampu mengembangkan bahasa dan simbol matematika sehingga dapat mengkomunikasikan secara lisan dan tulisan, mampu menggambarkan secara visual dan merefleksikan gambar atau diagram ke dalam ide matematika, mampu merumuskan dan mampu memecahkan masalah melalui penemuan.

Experiential Learning mendefinisikan belajar sebagai "proses bagaimana pengetahuan diciptakan melalui perubahan bentuk pengalaman. Pengetahuan diakibatkan oleh kombinasi pemahaman dan mentransformasikan pengalaman" Kolb adalah penemunya, mengusulkan bahwa experiential learning mempunyai enam karakteristik utama, yaitu:

1. Belajar terbaik dipahami sebagai suatu proses. Tidak dalam kaitannya dengan hasil yang dicapai.

2. Belajar adalah suatu proses kontinyu yang didasarkan pada pengalaman.

3. Belajar memerlukan resolusi konflik-konflik antara gaya-gaya yang berlawanan dengan cara dialektis.

4. Belajar adalah suatu proses yang holistik.

5. Belajar melibatkan hubungan antara seseorang dan lingkungan.

6. Belajar adalah proses tentang menciptakan pengetahuan yang merupakan hasil dari hubungan antara pengetahuan sosial dan pengetahuan pribadi. Experiential learning itu adalah proses belajar, proses perubahan yang

menggunakan pengalaman sebagai media belajar atau pembelajaran. Experiential Learning adalah pembelajaran yang dilakukan melalui refleksi dan juga melalui suatu proses pembuatan makna dari pengalaman langsung. Mahfudin menyimpulkan bahwa model Experiential learning dapat didefinisikan sebagai tindakan untuk mencapai sesuatu berdasarkan pengalaman yang secara terusmenerus mengalami perubahan guna meningkatkan keefektifan dari hasil belajar. ${ }^{4}$

Experiential Learning adalah suatu pendekatan yang dipusatkan pada siswa yang dimulai dengan landasan pemikiran bahwa orang-orang belajar terbaik itu dari pengalaman. Dan untuk pengalaman belajar yang akan benar-benar efektif,

\footnotetext{
${ }^{4}$ Abdul Majid, Belajar dan Pembelajaran Pendidikan Agama Islam, (Bandung: PT Remaja Rosdakarya, 2012), hlm. 181.
} 
harus menggunakan seluruh roda belajar, dari pengaturan tujuan, melakukan observasi dan eksperimen, memeriksa ulang, dan perencanaan tindakan. Apabila proses ini telah dilalui memungkinkan siswa untuk belajar keterampilan baru, sikap baru atau bahkan cara berpikir baru. Jadi, experiential learning adalah suatu bentuk kesengajaan yang tidak disengaja (unconsencious awareness).

Pengertian motivasi menurut $\mathrm{H}$. Mulyadi menyatakan bahwa definisi atau pengertian motivasi belajar adalah membangkitkan dan memberikan arah dorongan yang menyebabkan individu melakukan perbuatan belajar. ${ }^{5}$ Motivasi belajar adalah suatu dorongan kehendak yang menyebabkan seseorang melakukan suatu perbuatan untuk mencapai tujuan tertentu. Dalam belajar, tingkat ketekeunan siswa sangat ditentukan oleh adanya motif dan kuat lemahnya motivasi belajar yang ditimbulkan motif tersebut.

Motivasi merupakan suatu proses psikologis yang mencerminkan sikap, kebutuhan, persepsi dan keputusan yang terjadi pada diri seseorang. Motivasi sebagai proses psikologis timbul diakibatkan oleh faktor di dalam diri seseorang itu sendiri (faktor instrinsik) dan diluar diri orang tersebut (faktor ekstrinsik).

Dalam kaitannya dengan belajar siswa, motivasi belajar sangat diperlukan. Diyakini bahwa hasil belajar akan meningkat kalau siswa mempunyai motivasi belajar yang kuat. Motivasi belajar adalah keinginan siswa untuk mengambil bagian di dalam proses pembelajaran. Siswa pada dasarnya termotivasi untuk melakukan suatu aktivitas untuk dirinya sendiri karena ingin mendapatkan kesenangan dari pelajaran, atau merasa kebutuhannya terpenuhi. Ada juga siswa yang termotivasi melaksanakan belajar dalam rangka memperoleh penghargaan atau menghindari hukuman dari luar dirinya sendiri, seperti: nilai, tanda penghargaan, atau pujian guru.

Dari uraian yang tersebut di atas, dapat disimpulkan bahwa pengertian motivasi belajar adalah keseluruhan daya penggerak baik dari dalam diri maupun dari luar siswa (dengan menciptakan serangkaian usaha untuk menyediakan kondisi-kondisi tertentu) yang menjamin kelangsungan dan memberikan arah pada kegiatan belajar, sehingga tujuan yang dikehendaki oleh subjek belajar itu dapat tercapai.

\footnotetext{
${ }^{5}$ Abin Syamsudin Makmun, Psikologi Kependidikan, Jakarta: Remaja Rosda Karya, 2001,
} hlm. 87. 


\section{METODE PENELITIAN}

1. Subjek dan Objek Penelitian

Subjek dalam penelitian ini adalah siswa kelas VIII MTsN 2

Padangsidimpuan terdiri dari VIII-A yang berjumlah 29 orang siswa dan VIII-B yang berjumlah 30 orang siswa. Sedangkan yang menjadi objek dalam penelitian ini adalah penerapan model pembelajaran Experiential Learning untuk meningkatkan komunikasi matematis dan motivasi belajar siswa pada materi unsur-unsur lingkaran di kelas VIII MTsN 2 Padangsidimpuan.

\section{Desain Penelitian}

Penelitian ini merupakan penelitian kuantitatif dengan metode penelitian semu (quasi eksperimen design) yaitu penelitian yang terdiri dari satu atau beberapa kelompok eksperimen dan satu kelompok kontrol. Dalam penelitian ini terdapat satu kelompok eksperimen dan satu kelompok kontrol. Kelompok yang digunakan merupakan intact group (kelompok utuh) dan variabel terikat.

\section{HASIL DAN PEMBAHASAN PENELITIAN}

Setelah dilakukan proses belajar mengajar yang berbeda pada kelas eksperimen dan kelas kontrol, diperoleh data yang terlihat pada tabel berikut:

Tabel 2. Ringkasan Nilai Hasil Belajar Siswa Pada Materi Relasi

\begin{tabular}{|c|c|c|c|}
\hline \multirow{2}{*}{ Kelas } & \multirow{2}{*}{$\begin{array}{l}\text { Jumlah } \\
\text { Siswa }\end{array}$} & \multicolumn{2}{|c|}{ Rata-rata } \\
\hline & & Pre-test & Post-test \\
\hline Eksperimen & 29 & 54,00 & 78,79 \\
\hline Kontrol & 30 & 53,00 & 72,33 \\
\hline \multicolumn{2}{|c|}{ Selisih } & 1,00 & 6,46 \\
\hline
\end{tabular}

Tabel di atas menunjukkan bahwa nilai rata-rata pre-test kelas eksperimen dan kelas kontrol yaitu 54,00 dan 53,00 sehingga terlihat perbandingan yang sangat kecil yakni kedua kelas tersebut memiliki nilai ratarata yang hampir sama atau seimbang dan dapat disimpulkan bahwa kemampuan kedua kelas dianggap sama. Sedangkan nilai rata-rata post-test kelas eksperimen dan kelas kontrol setelah proses belajar mengajar mengalami peningkatan dari nilai rata-rata pre-test kedua kelas yakni 78,79 dan 72,33. Tabel di atas juga dapat digambarkan dalam bentuk diagram seperti berikut: 


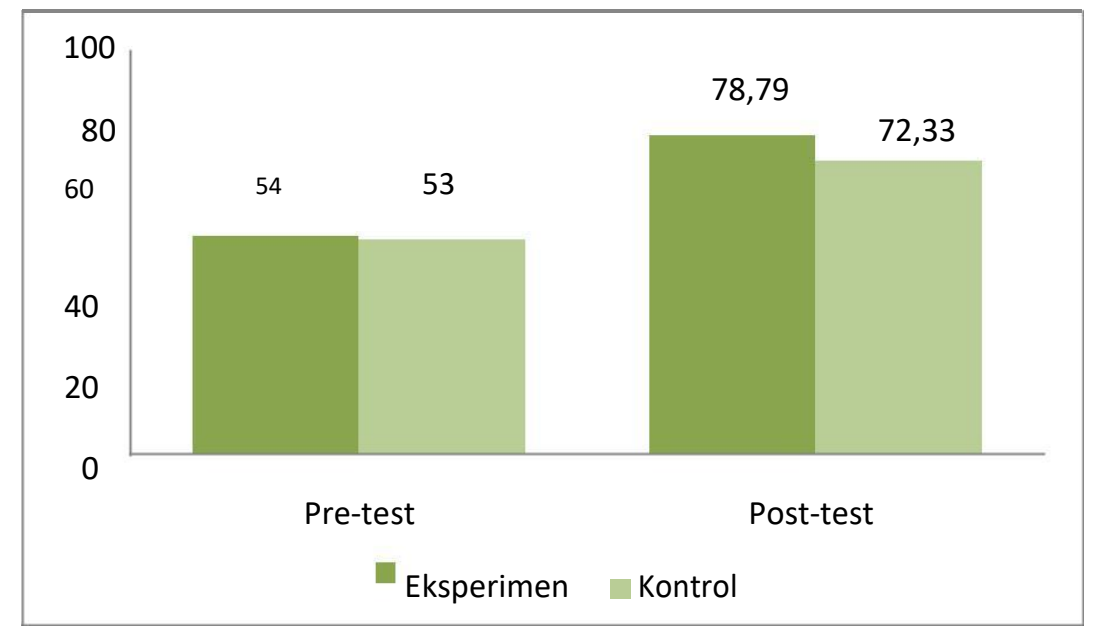

Gambar 1 Diagram Hasil Belajar Siswa

Berdasarkan tabel dan diagram di atas jelas bahwa hasil belajar siswa kelas eksperimen dan kelas kontrol sebelum proses belajar mengajar berlangsung memiliki selisih nilai rata-rata yang sangat kecil sehingga dapat disimpulkan bahwa kemampuan kedua kelas dianggap sama. Sedangkan hasil belajar siswa kedua kelas setelah proses belajar mengajar memiliki selisih yang signifikan yaitu sebesar 6,46 sehingga dapat disimpulkan bahwa hasil belajar siswa kelas eksperimen lebih baik dari pada kelas kontrol.

Berdsarkan hasil perhitungan dan pengujian motivasi belajar siswa menggunakan uji Tukey pada $\alpha=0,05$ untuk pengujian motivasi belajar siswa, diperoleh $Q$ hitung $=8,05$ lebih besar dari pada Qtabel $=4,08$. Dengan demikian, motivasi belajar siswa teruji kebenarannya secara signifikan dan dapat diterima. Maka, dapat disimpulkan bahwa pada kelompok siswa yang memiliki motivasi belajar rendah, ternyata diperoleh temuan bahwa hasil belajar kemampuan komunikasi matematis siswa yang diajar melalui pendekatan experiential learning lebih tinggi secara signifikan daripada yang diajar melalui pendekatan konvensional. Hal tersebut ditunjukkan pula dari hasil analisis deskriptif bahwa pada kelompok siswa yang memiliki motivasi belajar rendah, siswa yang diajar

melalui pendekatan experiential learning memperoleh skor hasil belajar matematika: mean 20,2; modus 21; simpangan baku 2,5; skor tertinggi 23 dan skor terendah 15 dari skor total 30 . Apabila mereka diajar dengan pendekatan konvensional, diperoleh hasil belajar matematika: mean 13,1; modus 11; simpangan baku 4,0; skor tertinggi 19 serta skor terendah 6 dari skor total 30 .

Dengan demikian, peneliti berpendapat bahwa model pembelajaran Experiential Learning dapat meningkatkan kemampuan komunikasi matematis dan 
motivasi belajar siswa secara signifikan. Selanjutnya untuk aktivitas siswa selama proses pembelajaran menunjukkan keaktifan siswa yang tinggi.

\section{KESIMPULAN}

Berdasarkan hasil penelitian dan analisis data maka dapat disimpulkan bahwa dengan model pembelajaran Experiential Learning dapat meningkatkan kemampuan komunikasi matematis dan motivasi belajar siswa memahami unsur-unsur lingkaran di kelas VIII MTsN 2 Padangsidimpuan.

Bertolak dari hasil pengujian hipotesis penelitian dan analisis data yang dilakukan, dapat disimpulkan beberapa hal seperti berikut. Pertama, hasil belajar kemampuan komunikasi matematis siswa yang diajar dengan pendekatan experiential learning lebih tinggi dari pada yang diajar dengan pendekatan pembelajaran konvensional. Dalam hal ini, pendekatan pembelajaran experiential learning lebih efektif daripada pendekatan pembelajaran konvensional dalam pembelajaran matematika di MTsN 2 Padangsidimpuan. Kedua, terdapat pengaruh interaksi antara pendekatan pembelajaran matematika dan motivasi belajar terhadap hasil belajar siswa. Fenomena ini menunjukkan adanya pengaruh hubungan timbal balik antara pendekatan pembelajaran experiential learning dan motivasi belajar dalam meningkatkan hasil belajar kemampuan komunikasi matematis siswa MTsN 2 Padangsidimpuan. Ketiga, pada kelompok siswa yang bermotivasi belajar rendah terlihat bahwa hasil belajar siswa yang diajar dengan pendekatan $\mathrm{P}$ experiential learning lebih tinggi daripada yang diajar dengan pendekatan pembelajaran konvensional. Hasil ini mengindikasikan bahwa pembelajaran experiential learning dapat meningkatkan motivasi belajar siswa sehingga pendekatan experiential learning lebih efektif daripada pendekatan pembelajaran konvensional dalam meningkatkan hasil belajar kemampuan komunikasi matematis siswa di MTs. 


\section{DAFTAR PUSTAKA}

Hodiyanto, Kemampuan Komunikasi Matematis dalam Pembelajaran Matematika, Jurnal AdMathEdu / Vol.7 No.1 Juni 2017

Majid, Abdul, Belajar dan Pembelajaran Pendidikan Agama Islam, 2012, (Bandung: PT Remaja Rosdakarya,).

Makmun, Abin Syamsudin, Psikologi Kependidikan, 2001, (Jakarta: Remaja Rosda Karya).

Nelissen, J.M.C. (2005). Thinking Skill in realistics mathematics. Jmc_nelissen : Journal PME. Vol 2 p 108-119 2005.

Wardhani, Sri. Analisis SI dan SKL mata pelajaran matematika SMP/MTs untuk optimalisasi tujuan mata pelajaran matematika. Yogyakarta: Pusat Pengembangan dan Pemberdayaan Pendidik dan Tenaga Kependidikan Matematika. 2008. 